\title{
Genetic drift in six cultivated populations of Terminalia arjuna
}

\author{
Pramod Kumar Sairkar*, Shweta Chouhan, Amit Sen, Rajesh Sharma, Raj Kumar Singh \\ Centre of Excellence in Biotechnology, M.P. Council of Science \& Technology, Vigyan Bhavan, Nehru Nagar, Bhopal, Madhya Pradesh, India.
}

\section{ARTICLE INFO}

Article history:

Received on: 09/01/2017

Accepted on: 12/04/2017

Available online: 14/08/2017

Key words:

Terminalia arjuna, genetic and molecular diversity, population genetics, relative differentiation and gene flow, AMOVA,

polymorphic information content

$(P I C)$, heterozygosity,

\begin{abstract}
Low genetic diversity among five cultivated populations of Terminalia arjuna was revealed using DNA fingerprints generated by ten commercially available random (RAPD) primers i.e. RPI01 to RPI10. Out of ten primers, eight primers generated total 79 bands with 87.34 percentage of polymorphism, while primer RPI02 and RPI08 did not show amplification. Applied all 8 primes having a good polymorphic informativeness among the populations (mean PIC $=0.355 \pm 0.032$ and $H o=0.463 \pm 0.018$ ). Higher genetic variation, gene diversity $(H)$, Shannon's Information index $(I)$ and Percentage of polymorphic bands $(P P B)$ among populations $(H=0.290 \pm 0.162, I=0.440 \pm 0.221$ and $P P B=87.34 \%)$ was observed compared to within populations (maximum $H=0.165 \pm 0.212, \mathrm{I}=0.239 \pm 0.304$ and $P P B=39.24 \%$, minimum $H=0.026 \pm$ $0.104, I=0.038 \pm 0.150, P P B=06.33 \%)$. Low average gene diversity $(\pi=0.075 \pm 0.062)$ within population, higher pair-wise $F$ st (ranged from 0.498 to 0.844 ) among the population and Analysis of Molecular Variance (AMOVA) shown adequate genetic variation among population $(P v=75.57 \%)$ but serious low genetic variation within populations $\left(P v=24.43, \Phi_{S T}=0.756\right)$. Among the populations of $T$. arjuna the higher relative differentiation $\left(G_{S T}=0.7843\right)$ with restricted gene flow $G_{S T}(N m)=0.1375$ was observed. Unbiased measures of genetic distance and phylogram revealed that all locations have their once genetic identity and they arranged in their respective clusters. Lowest distance was shown by accession collected from JNKVV and TFRI Jabalpur.
\end{abstract}

\section{INTRODUCTION}

In the last few decades, civilization and industrialization have been increased for the fulfilment of demand of rising population and which directly or indirectly effects on natural forest in the both developed and developing countries. Plantation forestry is most suitable and used approach for commercial production of forest wood as well as forest restoration [1, 2]. Enormous nurseries and clonal propagation laboratories are affianced in large scale production of plantlets and this genetically similar plant are beneficial for commercial forest wood production [3], but in other hand, this practice creates genetic drift in restoration of forest [4, 5]. Restoration of medicinal plants in the forest using nursery and clonal propagated plantlets creates genetic drift due to higher genetic similarity of mother and daughter plants. Medicinal plants play an important

\footnotetext{
* Corresponding Author

Pramod Kumar Sairkar, Centre of Excellence in Biotechnology, M.P. Council of Science \& Technology, Vigyan Bhavan, Nehru Nagar, Bhopal, Madhya Pradesh, India. Email: sairkar_pramod04 @ yahoo.com
}

role in health carein developing countries, especially in remote areas and many loca healthcare systems were successfully used by local communities since ancient time $[6,7,8]$. A major healthcare system 'Ayurveda' having long, rich history in India and now most accepted worldwide, especially in developed countries because of its fewer side effects [9]. The popularity and demand of herbal produces adversely affected their viability in natural habits as a result of unsustainable exploitation of these wild sources has directed to many species being extinct, threatened or endangered $[10,11]$. For the assessment of genetic viability of any species, estimation of genetic diversity, especially using molecular markers may play as an important tool. Many biochemical and molecular markers are routinely used for genetic diversity assessment, out of them random amplified polymorphic DNA analysis is most frequently used due to its simplicity and convenience $[12,13]$. India has one of the richest natural resources and estimated to be around 25,000 effective plant-based formulations, used in folk medicine. It is estimated that there are over 7,800 medicinal drug-manufacturing units in India, which consume about 2,000 tonnes of herbs annually [9]. T. arjuna is one of the most important medicinal plants and used in Ayurveda from ancient time in India. 
T. arjuna (family Combretaceae) is a large deciduous 6090 feet heighted and 2-2.5 m diameter at breast height tree found throughout India. This tree is usually an evergreen tree with new leaves appearing in the hot season (February to April) before leaf fall [14]. The thick white-to-pinkish-grey bark of $T$. arjuna has a wide spectrum of biological activity like anti-dysentric, antipyretic, astringent, cardiotonic, lithotriptic, anticoagulant, hypolipidemi, antimicrobial [15] and antiuremic [16] agent. Many active constituents include tannins, triterpenoidsaponins (arjunic acid, arjunolic acid, arjungenin, arjunglycosides), flavonoids (Argonne, arjunolone, luteolin), Gallic acid, ellagic acid, oligomericproanthocyanidins (OPCs), phytosterols, calcium, magnesium, zinc, and copper $[17,18,19]$ was identified in $T$. arjuna. Wild and cultivated Fruit (Seed) and Bark (Stem) are used in Ayurveda, Folk, Homoeopathy, Siddha, Tibetan, Unani and Western system of medicine with estimated annual trade of 2000 5000 metric ton / annum (NMPB).

\section{MATERIAL AND METHODS}

Total 28 samples of $T$. ajuna were collected from Bhopal, Sagar, Gwalior, Chitrakoot and 2 places of Jabalpur (Madhya Pradesh) and conserved at MPCST Human Herbal Health Care Garden Bhopal (table 1).

\subsection{DNA Isolation}

Young leaves of T. ajuna were used for isolation of genomic DNA from HEPES Based Method [20, 21]. The yield of DNA was measured using Nano Drop UV-Spectrophotometer (ND-1000) at $260 \mathrm{~nm}$ using DNase RNase free water as a blank.

\subsection{Amplified of DNA using RAPD markers}

Ten commercially available RAPD primers (table 2) from Bangalore Genei, Bangalore were used in the amplification of 28 accessions of 6 populations. $25 \mathrm{ng}$ Genomic DNA was amplification using Eppendorf gradient automatic thermal cycler. A PCR reaction of $50 \mu$ lwas prepared, adding $25 \mu \mathrm{l}$ of $2 \times$ red dye PCR master mix (10 mMTris-HCl, $50 \mathrm{mMKCl}, 1.5 \mathrm{mM} \mathrm{MgCl} 2$, 25 units/ml Taq DNA polymerase, 0.2 mMdNTPs, 5\% glycerol, $0.08 \%$ NP-40 and $0.05 \%$ Tween-20), $2 \mu$ lprimer, $1 \mu$ lemplate DNA (25 ng/ $\mu \mathrm{l}), 22 \mu \mathrm{l}$ sterile DNase RNase Free water and PCR enhancement agents BSA (400 ng/ $\mu \mathrm{l})$. Condition of thermal cycler was set at initial denaturation of the DNA at $94{ }^{\circ} \mathrm{C}$ for $5 \mathrm{~min}, 08$ cycles of $45 \mathrm{~s}$ at $94{ }^{\circ} \mathrm{C}, 1 \mathrm{~min}$ at $55^{\circ} \mathrm{C}$ and $1.5 \mathrm{~min}$ at $72{ }^{\circ} \mathrm{C} ; 30$ cycles of $45 \mathrm{~s}$ at $94{ }^{\circ} \mathrm{C}, 1 \mathrm{~min}$ at $58{ }^{\circ} \mathrm{C}$ and $1 \mathrm{~min}$ at $72{ }^{\circ} \mathrm{C}$ and final extension at $72{ }^{\circ} \mathrm{C}$ at $10 \mathrm{~min}$ and a hold temperature at $4{ }^{\circ} \mathrm{C}$. Control reactions without template DNA (negative control) and without the enzyme (positive control) were also run in the experiments. All the experiments were repeated thrice to ensure reproducibility. Amplified DNA fragments with a low range DNA ruler was separated by electrophoresis at 6-7 V/cm in TAE buffer for $3-4 \mathrm{~h}$ on $1.2 \%$ Agarose gel stained with Ethidium Bromide and photographed by Gel Documentation System (Alpha Innotech). Raw gel images were recorded and analysed through Alphaview software.

\subsection{Statistical analysis}

The molecular weight of all bands was calculated and binary matrix was prepared by scoring (0) as absence and (1) as the presence for all RAPD primers. Percentage of polymorphism was calculated according to the presence and absence of bands for all RAPD primers. For each RAPD markers, polymorphic information content $(P I C)$ and heterozygosity $(H)$ were calculated using online Software PICcalc (http://w3.georgikon.hu/pic/english/kodom.aspx) [22]. Similarity indices, distance matrix and phylogenetic tree were prepared using the PAST Software [23], using Jaccard's coefficient and UPGMA. Observed number of alleles $(\mathrm{Na})$, Effective number of alleles $(\mathrm{Ne})$ described by Welsh and McClelland [24], gene diversity $(H)$ described by Nei [25], Shannon's information index (I) described by Lewontin [26], Relative differentiation $\left(G_{S T}\right)$, estimate of gene flow from $\left(G_{S T}(\mathrm{Nm})\right)$, total heterozygosity $(\mathrm{Ht})$, within population heterozygosity $(H s)$, genetic identity and genetic distance within population described by McDermott and McDonald [27], Number of Polymorphic Bands $(N P B)$ and Percentage of polymorphic bands $(P P B)$ were calculated using Popgene version 1.31. Average genetic distances in the all populations was calculated and phylogenetic tree was analysed using MEGA5 software version 5 [28].

Average gene diversity $(\pi)$, molecular diversity $\left(\theta_{S}\right.$ and $\theta \pi$ ), matrix of pairwise $F_{S T}$ (Genetic distances between populations), Average pairwise differences [29], Analysis of Molecular Variance (AMOVA), Sum of squares (SS), Variance components $(V c)$, Percentage of variation $(P v)$ and Fixation Index $\left(\Phi_{S T}\right)$ were calculated using software Arlequin version 3.5 [30].

\section{RESULT}

Isolated DNA from all 28 accessions of 6 populations of T. arjuna was amplified using ten plant RAPD primer (table 2) and observed under UV light after resolving on $1.5 \%$ agarose gel with low range molecular marker.

\subsection{Genetic diversity, according to primers}

Percentage of polymorphism was calculated according to the presence and absence of bands for use primers. Out of ten primers, eight primers generated total 79 bands with $9.875 \pm 2.10$ meanbands per primer while primer RPI02 and RPI08 did not show amplification. Out of 79 bands total 69 polymorphic bands $(87.34 \%)$ were observed with average $8.625 \pm 2.330$ polymorphic bands per primer. Maximum percentage of polymorphic bands (100.00) were observed in RPI-07 and minimum 66.67 was observed in RPI-06 primer. Among the populations, mean of heterozygosity $(\mathrm{Ho})$ observed was $0.463 \pm 0.018$ with $0.355 \pm$ 0.032 of mean polymorphic information content (PIC) (table 3 ) 


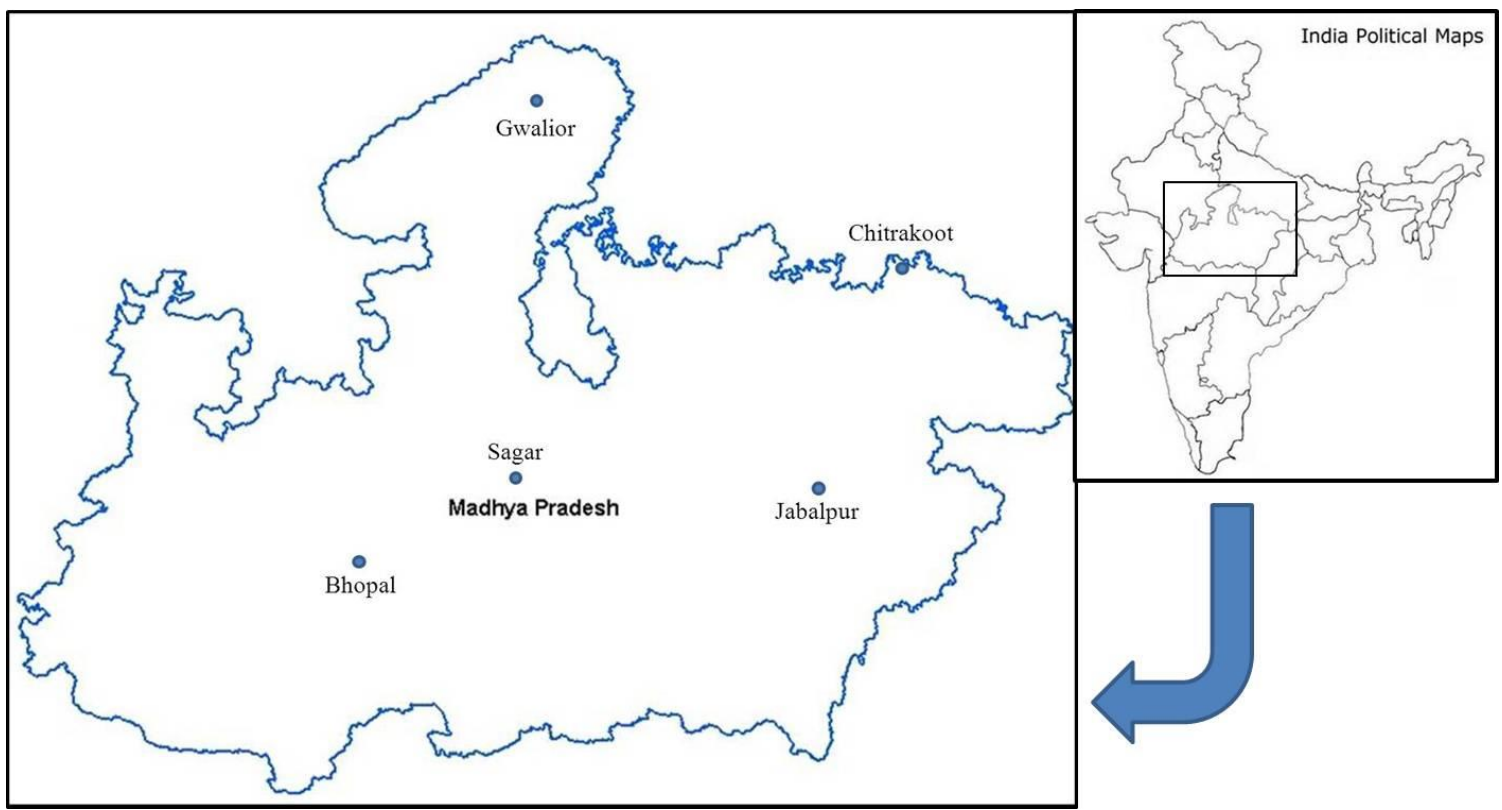

Fig. 1: Location of Sample collection.

Table 1: T. ajunafrom different locations.

\begin{tabular}{clccc}
\hline SL & \multicolumn{1}{c}{ Location of Collection } & Sample Code & Population & No of Sample \\
\hline 1 & Tropical Forest Research Institute, Jabalpur & JTTA-01 to 05 & JTTA & 5 \\
2 & Gwalior & GTA-01 to 05 & GTA & 5 \\
3 & Jawaharlal Agricultural University, Jabalpur & JJTA-01 to 05 & 5 & 3 \\
4 & Chitrakoot & CTA-01 to 03 & CTA & 4 \\
5 & Bhopal & BTA-01 to 04 04 & BTA & Total \\
6 & Sagar & STA-01 to 06 & STA \\
\hline
\end{tabular}

Table 2: RAPD Primers for the molecular diversity analysis.

\begin{tabular}{cccc}
\hline SL & Name of Primer & & Accession No. \\
\hline 1. & RPI -01 & $:$ & AM 765819 \\
2. & RPI -02 & $:$ & AM750044 \\
3. & RPI -03 & $:$ & AM 773310 \\
4. & RPI -04 & $:$ & AM 773769 \\
5. & RPI -05 & $:$ & AM 773770 \\
6. & RPI -06 & $:$ & AM 773771 \\
7. & RPI -07 & $:$ & AM 773312 \\
8. & RPI -08 & $:$ & AM 773773 \\
9. & RPI -09 & $:$ & AM 773315 \\
10. & RPI -10 & $:$ & A \\
\hline
\end{tabular}

Table 3: Genetic diversity, according to primers.

\begin{tabular}{|c|c|c|c|c|c|c|}
\hline SL & Primer & Total bands & $N P B$ & $P P B$ & $H$ value & $P I C$ value \\
\hline 1 & RPI01 & 10 & 9 & $90.00 \%$ & 0.476 & 0.362 \\
\hline 2 & RPI02 & 0 & - & - & -- & -- \\
\hline 3 & RPI03 & 10 & 9 & $90.00 \%$ & 0.480 & 0.365 \\
\hline 4 & RPI04 & 10 & 9 & $90.00 \%$ & 0.417 & 0.330 \\
\hline 5 & RPI05 & 13 & 11 & $84.62 \%$ & 0.497 & 0.374 \\
\hline 6 & RPI06 & 9 & 6 & $66.67 \%$ & 0.475 & 0.362 \\
\hline 7 & RPI07 & 12 & 12 & $100.00 \%$ & 0.470 & 0.360 \\
\hline 8 & RPI08 & 0 & - & - & -- & -- \\
\hline 9 & RPI09 & 9 & 8 & $88.89 \%$ & 0.408 & 0.325 \\
\hline \multirow[t]{2}{*}{10} & RPI10 & 6 & 5 & $83.34 \%$ & 0.480 & 0.365 \\
\hline & Total & 79 & 69 & $87.34 \%$ & & \\
\hline \multicolumn{2}{|c|}{ Mean \pm SD } & $9.875 \pm 2.100$ & $8.625 \pm 2.330$ & & $0.463 \pm 0.018$ & $0.355 \pm 0.032$ \\
\hline
\end{tabular}


Table 4: Genic Variation Statistics for All Loci Nei (1987).

\begin{tabular}{|c|c|c|c|c|c|c|c|}
\hline Population & Sample Size & $\mathrm{Na}$ & $\mathrm{Ne}$ & $H$ & $I$ & $N P B$ & $P P B$ \\
\hline \multicolumn{8}{|l|}{ Within Population } \\
\hline JTTA & 5 & $1.063 \pm 0.245$ & $1.047 \pm 0.190$ & $0.026 \pm 0.104$ & $0.038 \pm 0.150$ & 5 & 06.33 \\
\hline GTA & 5 & $1.089 \pm 0.286$ & $1.076 \pm 0.250$ & $0.041 \pm 0.132$ & $0.057 \pm 0.186$ & 7 & 08.86 \\
\hline JJTA & 5 & $1.114 \pm 0.320$ & $1.077 \pm 0.228$ & $0.045 \pm 0.128$ & $0.066 \pm 0.187$ & 9 & 11.39 \\
\hline CTA & 3 & $1.101 \pm 0.304$ & $1.081 \pm 0.243$ & $0.045 \pm 0.135$ & $0.065 \pm 0.193$ & 8 & 10.13 \\
\hline BTA & 4 & $1.076 \pm 0.267$ & $1.056 \pm 0.202$ & $0.032 \pm 0.112$ & $0.046 \pm 0.163$ & 6 & 07.59 \\
\hline STA & 6 & $1.392 \pm 0.491$ & $1.295 \pm 0.389$ & $0.165 \pm 0.212$ & $0.239 \pm 0.304$ & 31 & 39.24 \\
\hline \multicolumn{8}{|l|}{ Among populations } \\
\hline & 28 & $1.873 \pm 0.335$ & $1.478 \pm 0.3203$ & $0.290 \pm 0.162$ & $0.440 \pm 0.221$ & 69 & 87.34 \\
\hline
\end{tabular}

$\mathrm{Na}=$ Observed number of alleles

$\mathrm{Ne}=$ Effective number of alleles [Kimura and Crow (1964)]

$H=$ Nei's (1973) gene diversity

$I=$ Shannon's Information index [Lewontin (1972)]

Table 5: Nei's Analysis of Gene Diversity in Subdivided Populations.

\begin{tabular}{cccccc}
\hline & Sample & $\boldsymbol{H t}$ & $\boldsymbol{H s}$ & $\boldsymbol{G s t}$ & $\boldsymbol{N m}^{*}$ \\
\hline Among population & 28 & $0.273 \pm 0.028$ & $0.059 \pm 0.005$ & 0.7843 & 0.1375 \\
\hline
\end{tabular}

$* \mathrm{Nm}=$ estimate of gene flow from Gst

$\mathrm{Nm}=0.5(1-\mathrm{Gst}) / \mathrm{Gst}$;

Table 6: Average gene diversity $(\pi)$ and molecular diversity $\left(\theta_{S}\right.$ and $\left.\theta \pi\right)$.

\begin{tabular}{cccc}
\hline SL & \multicolumn{2}{c}{ Molecular Diversity } & Average gene diversity $(\boldsymbol{\pi})$ \\
\cline { 2 - 4 } & $\boldsymbol{\theta}_{\boldsymbol{S}}$ & $\boldsymbol{\theta} \boldsymbol{\pi}$ & 0.033 \\
& 2.400 & 2.600 & 0.051 \\
JTTA & 3.360 & 4.000 & 0.056 \\
GTA & 4.320 & 4.400 & 0.068 \\
JJTA & 5.333 & 5.333 & 0.042 \\
CTA & 3.273 & 3.333 & 0.198 \\
BTA & 13.577 & 15.667 & $0.075 \pm 0.062$ \\
\hline STA & $5.377 \pm 4.14$ & $5.889 \pm 4.88$ & \\
\hline
\end{tabular}

\subsection{Genetic Variation}

For the estimation of genetic variation in the populations, Observed number of alleles $(\mathrm{Na})$, Effective number of alleles $(\mathrm{Ne})$, gene diversity $(H)$, Shannon's Information index $(I)$, Number of Polymorphic Bands $(N P B)$ and Percentage of polymorphic bands $(P P B)$ were calculated. According to this parameter within population STA maximum genetic variation $(\mathrm{Na}=1.392 \pm 0.491, \mathrm{Ne}=1.295 \pm 0.389, \mathrm{H}=0.165 \pm 0.212, \mathrm{I}=$ $0.239 \pm 0.304, N P B=31 \%$ and $P P B=39.24 \%$ ), was observed compared to other population and population JTT As how minimum genetic variation $(\mathrm{Na}=1.063 \pm 0.245, \mathrm{Ne}=1.047 \pm$ $0.190, H=0.026 \pm 0.104, I=0.038 \pm 0.150, N P B=5 \%$ and $\mathrm{PPB}=$ $06.33 \%$ ) (table 4). Compare to within population, among the populations higher genetic variations $(\mathrm{Na}=1.873 \pm 0.335$, $N e=1.478 \pm 0.320, H=0.290 \pm 0.162, I=0.440 \pm 0.221, H t=0.273$ \pm 0.028 and $H s=0.059 \pm 0.005, \mathrm{NPB}=69$ and $\mathrm{PPB}=87.34 \%$ was observed (table 4 , and 5).

\subsection{Relative differentiation and gene flow}

Among the populations of $T$. arjuna the Relative differentiation $\left(G_{S T}=0.4033\right)$ and estimate of gene flow from $G_{S T}(\mathrm{Nm})=0.7396$ was observed (table 5).

\subsection{Gene diversity and pairwise difference}

Mean of average gene diversity $(\pi)$ and molecular diversity $\left(\theta_{S}\right.$ and $\left.\theta \pi\right)$ was $0.075 \pm 0.062,5.377 \pm 4.14$ and $5.889 \pm$ 4.88 respectively, with maximum $\pi=0.198, \theta_{S}=13.577$ and $\theta \pi=$ 15.667 in population STA and minimum $\pi=0.033, \theta_{S}=2.4$ and $\theta \pi$ $=2.6$ in population JTTA was observed (table 6). Maximum $F_{S T}$ of 0.844 was observed in between a population of BTA and GTA, while minimum 0.498 was observed in between population BTA and CTA (table 7 , figure 2 ) with significance $(p=0.0500)$ at 110 permutations. The maximum average number of pair wise differences between populations STA and JTTA and minimums between populations JTTA and JJTA, while maximum corrected average pair wise difference (Nei's) between populations STA and JTTA and minimums between populations CTA and BTA was observed. The maximum average number of pair wise differences within population STA and minimum within population JTTA was observed (table 8 , figure 3 ).

\subsection{Analysis of Molecular Variants (AMOVA)}

Within populations and among populations, 75.57 and 24.43 Percentage of variation $(P v)$ respectively, with Fixation Index $\left(\Phi_{S T}\right) 0.756$ was calculated with significance level $p=0.001$ at 1023 permutations (table 9 ). 


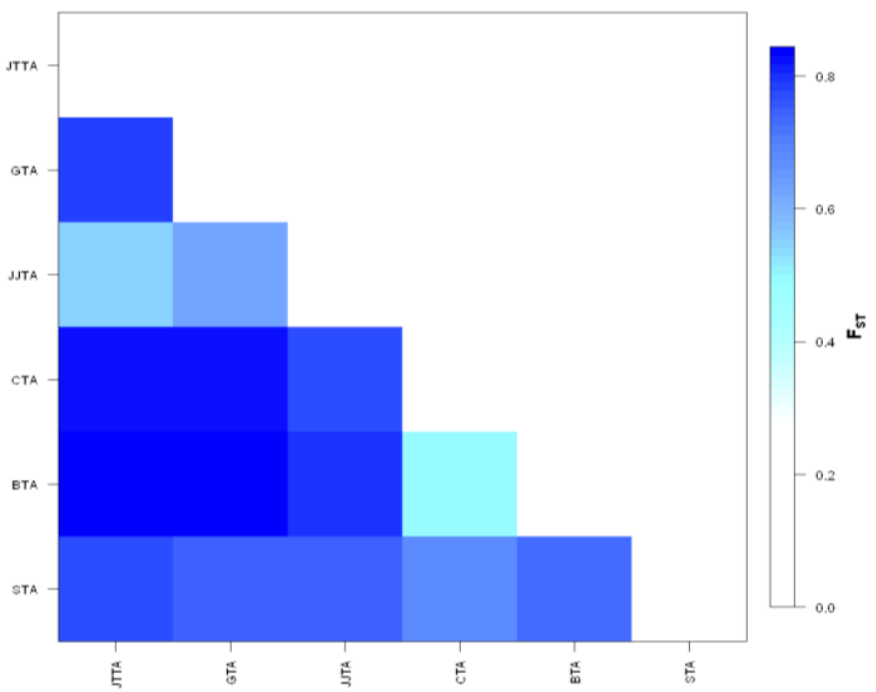

Fig. 2: Matrix of pair-wise Fst.

Table 7: Population pairwise $F_{S T}$.

\begin{tabular}{cccccc}
\hline & JTTA & GTA & JJTA & CTA & BTA \\
\hline JTTA & -- & & & & \\
GTA & $0.786^{*}$ & -- & - & & \\
JJTA & $0.544^{*}$ & $0.621^{*}$ & $0.770^{*}$ & - & - \\
CTA & $0.826^{*}$ & $0.823^{*}$ & $0.792^{*}$ & $0.498^{*}$ & $0.684^{*}$ \\
BTA & $0.841^{*}$ & $0.844^{*}$ & $0.743^{*}$ & $0.735^{*}$ & - \\
STA & $0.771^{*}$ & $0.748^{*}$ & & \\
\hline
\end{tabular}

Number of permutations: 110 .

$*$ Significance Level $(p)=0.0500$.

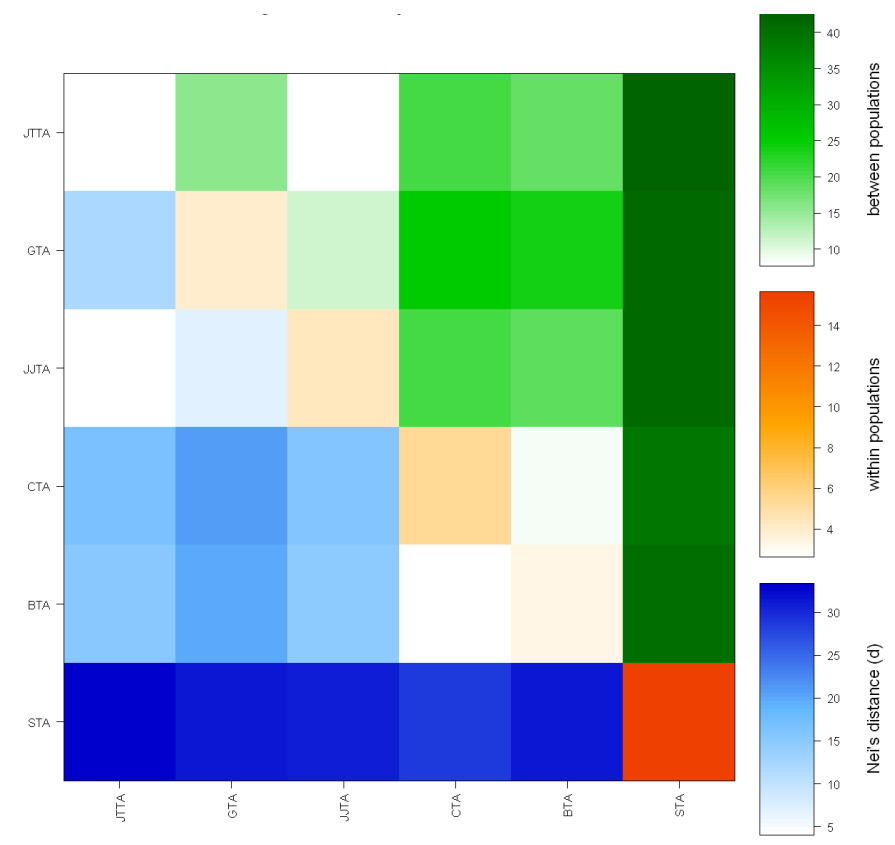

Fig. 3: Avarage number of pairwise distance.

Table 8: Distance method: Pairwise difference.

\begin{tabular}{ccccccc}
\hline & JTTA & GTA & JJTA & CTA & BTA & STA \\
\hline JTTA & 2.600 & 15.400 & 7.680 & 20.400 & 18.400 & 42.567 \\
GTA & 12.100 & 4.000 & 11.080 & 25.267 & 23.700 & 18.900 \\
JJTA & 4.180 & 6.880 & 4.400 & 20.533 & 4.233 & 8.333 \\
CTA & 16.433 & 20.600 & 15.667 & 4.000 & 3.100 & 3.333 \\
BTA & 15.433 & 20.033 & 15.033 & 28.444 & 31.167 & 40.667 \\
STA & 33.433 & 31.400 & 31.067 & 15.667 & \\
\hline
\end{tabular}

Above diagonal: Average number of pairwise differences between populations

Diagonal elements: Average number of pairwise differences within population.

Below diagonal: Corrected average pairwise difference. 
Table 9: Analysis of Molecular Variance (ANOVA).

\begin{tabular}{|c|c|c|c|c|c|}
\hline Source of variation & $\mathbf{D} f$ & $\begin{array}{c}\text { Sum of squares } \\
(S S)\end{array}$ & Variance components $(V c)$ & $\begin{array}{c}\text { Percentage of variation } \\
(P v)\end{array}$ & Fixation Index \\
\hline Among populations & 5 & 248.929 & 10.054 & 75.57 & $\Phi_{\mathrm{ST}}: 0.756^{*}$ \\
\hline Within populations & 22 & 71.500 & 03.250 & 24.43 & \\
\hline Total & 27 & 320.429 & 13.304 & & $P^{*}=<0.001$ \\
\hline
\end{tabular}

*Significant (1023 permutations)

Table 10: Unbiased Measures of Genetic distance.

\begin{tabular}{|c|c|c|c|c|c|c|}
\hline & JTTA & GTA & JJTA & CTA & BTA & STA \\
\hline JTTA & -- & & & & & \\
\hline GTA & 0.179 & -- & & & & \\
\hline JJTA & 0.062 & 0.103 & -- & & & \\
\hline CTA & 0.256 & 0.335 & 0.248 & -- & & \\
\hline BTA & 0.232 & 0.315 & 0.230 & 0.065 & -- & \\
\hline STA & 0.660 & 0.616 & 0.610 & 0.552 & 0.605 & -- \\
\hline
\end{tabular}

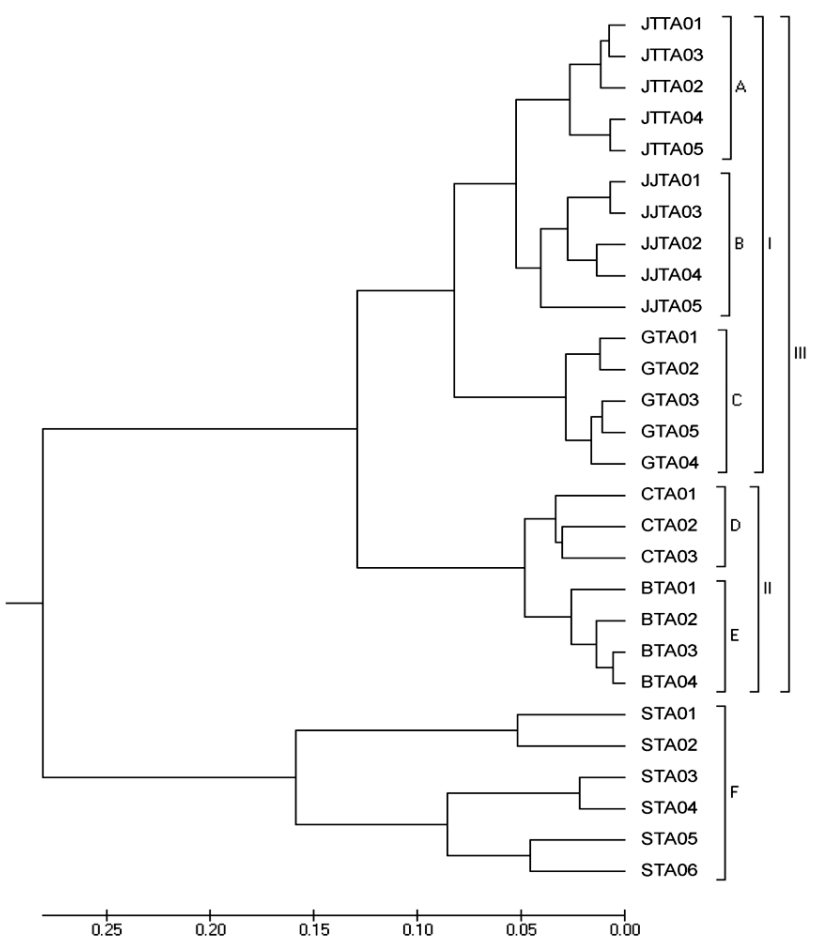

Fig. 4: Dendrogram of 28 accessions Based Nei's (1978) Genetic distance Method UPGMA

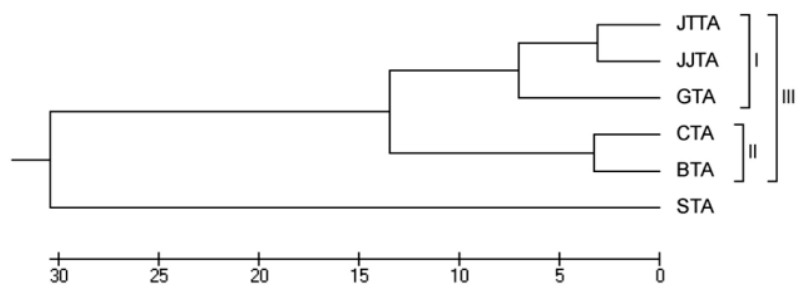

Fig. 5: Dendrogram of 6 populations Based Nei's (1978) Genetic distance Method UPGMA.

\subsection{Distance Matrix and phylogenetic}

Populations STA and JTTA showed maximum genetic distance $(D=0.660)$ and population JJTA and JTTA showed minimum genetic distance $(D=0.062)$. 0.338 Average genetic distances were calculated using MEGA5. When dendrogram (Phylogenetic tree) was prepared using a binary matrix of 28 accessions, six clusters, i.e. cluster A to cluster $\mathrm{F}$ were generated, which represent the accessions of their respective population (figure). Population JJTA and JTTA showed lowest genetic distance followed by population GTA and prepared a major cluster I. Population CTA and BTA create a cluster II, which is similar to cluster I and prepare a mega cluster called cluster III. Population STA was shown similarity with mega cluster III (table 10, figure 4 and 5). 


\section{DISCUSSION}

Medicinal plants are the source of a large number of essential drugs in Western medicine and are the basis of herbal medicine, which is not only the primary source of health care for most of the world's population living in developing countries but also enjoys growing popularity in developed countries. The increased demand for botanical products is met with an expanding industry and accompanied by calls for assurance of quality, efficacy and safety. Plants used as drugs, dietary supplements and herbal medicines are identified at the species level [31].

The genetic variability of a population is usually measured by the average hetrozygosity per locus, while the gene differences between two populations may be measured by the genetic distance recently proposed by Nei $[32,33]$. In this study, a total of 79 alleles was scored by 10 RAPD primers in 26 accessions, out of which, 69 alleles $(87.34 \%)$ were polymorphic in nature. Barker [3] suggested that loci with at least four alleles should be suitable for studying the genetic diversity. The alleles more than the recommended number observed in this study supports the suitability of markers [34]. Therefore, it revealed that the used primers had sufficient potency for population studies and this is the first report, which accesses the genetic diversity among and within populations of T. arjuna. The occurrence of low genetic diversity at the population level was also reported in many plant species [35, 36, 37, 38, 39, 40, 41].

The $P I C$ value of each RAPD primers was determined by both the number of alleles and their frequency distribution within a population and was used to assess their information level (high $P I C>0.5$, moderate $0.5>P I C>0.25$ and low $P I C<0.25)$ [42, 43]. Therefore, in this study, mean polymorphic information content $(P I C=0.355 \pm 0.032)$ of primers, showed moderate level of polymorphic information among six populations of used markers and suggested that these markers were equally effective in determining polymorphisms. The PIC value has been used for evaluating genetic variation in many studies using RAPD markers and other molecular markers [39, 44, 45, 46, 47, 48]

Genetic variation was estimated by various parameters; out of them the effective number of alleles is lesser than the observed number of all the lociin all calculations. Effective number of alleles and observed number of alleles among the population was found higher than within population, indicating more allelic polymorphism among the population, compared to within the population. Shannon's information index, which measures the level of diversity, further supports the suitability of markers, and occurrence of genetic polymorphism [49]. Observed and expected heterozygosity defines the probability that a given individual randomly selected from a population will be heterozygous at a given locus and the observed heterozygosities were lower than the expected [34]. This information index and heterozygosity also support the more diversity among the population, compared to within populations. The unbiased expected gene diversity (Nei's) ranged from 0.14 (OarJMP29) to 0.92 (ILSTS059) with the overall mean $0.73 \pm 0.19$. The F- estimates were applied to all the 25 studied loci to determine the extent of inbreeding in the population.

Gene flow is a collective term that includes all the mechanism resulting in the movement of genes from one population to another [50]. Higher relative differentiation in within groups was observed in comparing to the relative differentiation. On the other hand, gene flow was higher among the accessions in respect to the gene flow of within the groups. Assessment of gene flow from one population to another is an important statically parameter for study of genetic diversity. This parameter for enlightening diversity in many medicinal plants was successfully applied [51, 52, 53, 40].

The significance of the covariance components was calculated with the different possible levels of genetic structure (among groups, among populations within groups and within populations). Within populations and among populations, 75.57 and 24.43 Percentage of variation $(P v)$ respectively, with Fixation Index $\left(\Phi_{S T}\right) 0.756$ was calculated with significance level $\mathrm{p}=0.001$ at 1023 permutations. The significance of the covariance components with the different possible levels of genetic structure, including among groups, among populations within groups and within populations was extensively used for the study of molecular variance $[51,54]$.

\section{CONCLUSION}

Sustainable genetic diversity is an important issue for forest restoration more willingly than low genetic diversity is suitable for commercial forestry for their economic importance and value. Viable diversity upholds in platelets generated through clonal propagation and horticulture is slightly difficult and this may be created genetic drift.

\section{ACKNOWLEDGMENT}

The authors wish to thank Prof. PK Verma, Director General, MPCST for the providing laboratory facilities.

Conflict of Interests: There are no conflicts of interest.

\section{DATA ARCHIVING STATEMENT}

Genotypes of the individuals analyzed are available from the corresponding author after request.

\section{REFERENCES}

1. Chakravarty S, Ghosh SK, Suresh CP, Dey AN, Shukla G . Deforestation: Causes, Effects and Control Strategies, Global Perspectives on Sustainable Forest Management, Dr. Clement A. Okia (Ed.), , InTech, 2012. Available from: http://www.intechopen.com/books/globalperspectives-onsustainable-forest-management/deforestation-causes-effects-andcontrol-strategies.

2. Nabuurs GJ, O Masera, K Andrasko, P Benitez-Ponce, R Boer, M Dutschke, E Elsiddig, J Ford-Robertson, P Frumhoff, T Karjalainen, O Krankina, WA Kurz, M Matsumoto, W Oyhantcabal, NH 
Ravindranath, MJ Sanz Sanchez, X Zhang, 2007: Forestry. In Climate Change 2007: Mitigation. Contribution of Working Group III to the Fourth Assessment Report of the Intergovernmental Panel on Climate Change [B. Metz, O.R. Davidson, P.R. Bosch, R. Dave, L.A. Meyer (eds)], Cambridge University Press, Cambridge, United Kingdom and New York, NY, USA.

3. Barker JSF. Sequential gel electrophoretic analysis of esterase-2 in two populations of Drosophila buzzatii. Genetica. 1994; 92(3): 165-175.

4. Burgarella C, Navascués M, Soto Á, Lora Á, Fici S. Narrow genetic base in forest restoration with holm oak (Quercus ilex L.) in Sicily. Annals of Forest Science. 2007; 64(7):757-763.

5. Li YY, Chen XY, Zhang X, Wu TY, Lu HP, Cai YW. Genetic Differences between Wild and Artificial Populations of Meta sequo iaglypto stroboides: Implications for Species Recovery. Conservation Biology. 2005; 19(1):224-231.

6. Bekalo TH, SD Woodmatas, ZA Woldemariam. An ethnobotanical study of medicinal plants used by local people in the lowlands of Konta Special Woreda, Southern nations, nationalities and peoples regional state. Ethiopia. Journal of Ethnobiology and Ethnomedicine. 2009; 5:26.

7. Rao MR, MC Palada. BN Becker. Medicinal and aromatic plants in Agro forestry systems. 2004; (61): 107-122.

8. Mahonge CPI, JV Nsenga, Mtangi, AC Matte. Utilization of medicinal plants by Walguru people in east Uluguru mountains, Tanzania. African Journal of Traditional \& Alternative and Alternative Medicine. 2006 ; (4): 121-134.

9. Verma S, Singh SP. Current and future status of herbal medicines. Veterinary World. 2008; 1(11): 347-350

10. Omobuwajo OR, GO Alade, A Sowemimo. Indigenous Knowledge and practices of women herb sellers of Southwestern Nigeria. Indian Journal of Traditional Knowledge. 2008; 7(3): 505-510

11. Oladele AT, GO Alade, OR Omobuwajo. Medicinal plants conservation and cultivation by traditional medicine practitioners (TMPs) in Aiyedaade Local Government Area of Osun State, Nigeria. Agric. Biol. J. N. Am. 2011; 2(3): 476-487

12. Welsh J, McClelland M. Fingerprinting genomes using PCR with arbitary primers. Nuc. Acids Res. 1990; 18: 7213-7218.

13. Williams JGK, Kubelik AR, Livak KJ, Rafalski JA, Tingey SV. DNA polymorphism amplified by arbitrary primers are useful as genetic markers. Nuc. Acids Res. 1990; 1: 6531-6535.

14. Mandal S, Patra A, Samanta A, Roy S, Mandal A, Mahapatra TD, PradhanS, Das K, Nandi DK. Analysis of phytochemical profile of Terminalia arjuna bark extract with antioxidative and antimicrobial properties Asian Pac J Trop Biomed. 2013; 3(12): 960-966.

15. Mandal A, Das K, Nandi D K. In vitro bioactivity study of bark extract of Terminalia arjuna on probiotics, commercially available probiotic formulation. Int J Phytopharmacol. 2010; 1(2): 109-113.

16. Das K, Chakraborty PP, Ghosh D, Nandi DK. Protective effect of aqueous extract of Terminalia arjuna against dehydrating induced oxidative stress and uremia in male rat. Iran J Pharma Res. 2010; 9(2): 153-161.

17. Bone K. Clinical Applications of Ayurvedic and Chinese Herbs. Warwick, Queensland, Australia. Phytotherapy Press. 1996; 131-133.

18. Kapoor LD. Handbook of Ayurvedic Medicinal Plants. Boca Raton, FL. CRC Press. 1990; 319-320.

19. Nema R, Jain P, Khare S, Pradhan A, Gupta A, Singh D. Antibacterial and antifungal activity of Terminalia arjunaleaves extract with special reference to flavanoids. Basic Res J Med ClinSci1. 2012; (5): 63-65.

20. Deshmukh V.P., Thakare P.V., Chaudhari U.S., Gawande P.A. A simple method for isolation of genomic DNA from fresh and dry leaves of Terminalia arjuna (Roxb.) Wight and Argot. Electronic Journal of Biotechnology. 2007; 10(3):468-472.

21. Sairkar P, Chouhan S, Batav N, Sharma R. Optimization of DNA isolation process and enhancement of RAPD PCR for low quality genomic DNA of Terminalia arjuna. Journal of Genetic Engineering and Biotechnology. 2013a; 11(1):17-24.
22. Nagy S, Poczai P, Cernák I, Gorji AM, Hegedűs G and Taller J. PICcalc: an online program to calculate polymorphic information content for molecular genetic studies. Biochem Genet. 2012; 50(910):670-672

23. Hammer O, Harper DAT, PD Ryan. PAST: Paleontological Statistics Software Package for Education and Data Analysis. Palaeontologia Electronica. 2001; 4(1):9.

24. Kimura M, Crow JF. The Number of Alleles That Can Be Maintained In A Finite Population. Genetics. 1964; 49:725-38.

25. Nei M. Analysis of gene diversity in subdivided populations. Proceedings of the National Academy of Sciences, USA. 1973; 70, 3321-3.

26. Lewontin RC. Testing the theory of natural selection. Nature 1972; 236(5343): 181-182

27. McDermott JM, McDonald BA. Gene flow in plant pathosystems. Annual Review of Phytopathology, 1993; 31: 353-73.

28. Tamura K, Peterson D, Peterson N, Stecher G, Nei M, Kumar S MEGA5: Molecular Evolutionary Genetics Analysis using Likelihood, Distance, and Parsimony methods. Mol Biol Evol 2011; 28:2731-2739.

29. Nei M, Li WH. Mathematical model for studying genetic variation in terms of restriction endonucleases. Proc Natl Acad Sci USA 1979; 76:5269-5273.

30. Excoffier L, Laval G, Schneider S. Arlequin ver. 3.5: An integrated software package for population genetics data analysis. Evol Bioinfo Online, 2005; 1:47-50.

31. Sucher NJ, Carles MC. Genome-Based Approaches to the Authentication of Medicinal Plants. Planta Med, 2008; 74: 603-623.

32. Nei M 1971 Identity of genes and genetic distance between populations. Genetics 68: s47. --, 1972 Genetic distance between populations. Am. Naturalist 106: 283-292. -, 1973a A new measure of genetic distance. Genetic Distance. Edited by J. F. CROWP. Lenum Press, New York. (In press), 1973b The theory and estimation of genetic distance. Genetic Structure of Populations. Edited by N. E. MORTONU.niv. of Hawaii Press, Honolulu.

33. Nei M, AK Roychoudhury. Gene differences between Caucasian, Negro and Japanese populations. Science, 1972; 177: 434-436.

34. Mishra P, Ali AS, Kuralkar SV, Dixit SP, Aggarwal RAK, Dangi PS, Verma NK. Analysis of Genetic Diversity in Berari Goat Population of Maharashtra State. Iranian Journal of Applied Animal Science. 2013; 3(3): 553-559.

35. Yun R, Zhong M, Wang HX, Wei W, Qian YQ. Study on DNA diversity of Liadong Oak population at Dongling Mountain Region Beiging. Acta Botanica Sinica. 1998; 40(2):169-175.

36. Fu C, Qiu Y, Kong H. RAPD analysis for genetic diversity in Changium smyrnioides (Apiaceae), an endangered plant. Bot Bull Acad Sci. 2003; 44:13-18.

37. Vijay N, Sairkar P, Silawat N, Garg RK, Mehrotra NN. Genetic variability in Asparagus racemosus (Willd.) from Madhya Pradsh, India by random amplified polymorphic DNA. Afr J Biotech. 2009; 8(14):3135-3140.

38. Ginwal HS, Mittal N, Tomar A, Varshney VK. Population genetic structure and diversity of high value vulnerable medicinal plant Acorus calamus in India using RAPD and chloroplast microsatellite markers. J For Res. 2011; 22(3):367-377.

39. Wijarat P, Keeratinijakal V, Toojinda $T$, Vanavichit A, Tragoonrung S. Assessing genetic diversity of Andrographis paniculata (Burm f.) Nees, an important medicinal plant of Thailand using RAPD markers. Thai J Genet. 2011; 4(2):115-125.

40. Wang XM, Hou XQ, Zhang YQ, Yang R, Feng SF, Li Y, Ren Y. Genetic Diversity of the Endemic and Medicinally Important Plant Rheum officinale as Revealed by Inter-Simpe Sequence Repeat (ISSR) Markers. Int J Mol Sci. 2012a; 13:3900-3915.

41. Sairkar P, Vijay N, Batav N, Silawat N, Garg RK, Chouhan S, Sharma R, Mehrotra NN. Genetic Variability in Two Economically Important Medicinal Plants of Madhya Pradesh, India and Withania SomniferaRauwolfia Serpentina Using RAPD Markers. Asian J Exp Biol Sci. 2013b; 4(1):36-43. 
42. Bostein D, White RL, Skolnick M, Davis RW. Construction of a Genetic Linkage Map in Man Using Restriction Fragment Length Polymorphisms. Am J of Human Genet. 1980; 32:314-331.

43. Weber RP. Basic Content Analysis. Sage Publications, Newburry Park, CA. 1990

44. Bhattacharya S, Bandopadhyay TK, Ghosh PD. Efficiency of RAPD and ISSR markers in assessment of molecular diversity in elite germplasms of Cymbopogon winterianus across West Bengal, India. Emir J Food Agric. 2010; 22(1):13-24.

45. Tripathi N, Chouhan DS, Saini N, Tiwari S. Assessment of genetic variations among highly endangered medicinal plant Bacopa monnieri (L.) from Central India using RAPD and ISSR analysis. Biotech. 2012; 2:327-336.

46. Lal S, Mistry KN, Chaturvedi SP. Random Amplified Polymorphic DNA (RAPD) Fingerprinting for Evaluation of Interspecific Catharanthus roseus Populations Collected from Gujrat, India. Int J Biol Pharma Alli Sci. 2013; 2(2):373-385.

47. Muthusamy S, Kanagarajan S, Ponnusamy S. Efficiency of RAPD and ISSR markers system in accessing genetic variation of rice bean (Vigna umbellata) landraces. Electronic J Biotech. 2008; 11(3):110.

48. Sadeghi A, Cheghamirza K. Efficiency of RAPD and ISSR marker systems for studying genetic diversity in common bean (Phaseolus vulgaris L.) cultivars. Ann Biol Res. 2012; 3(7):3267-3273.

49. Kesari V, VM Sathyanarayana, A Parida, L Rangan. Molecular marker-based characterization in candidate plus trees of Pongamia pinnata, a potential biodiesel legume. AoB Plants. 2010; plq017.
50. Slatkin M. A measure of population subdivision based on microsatellite allele frequencies. Genetics. 1985; 139:457-462.

51. Shi W, Yang CF, Chen JM, Guo YH. Genetic variation among wild and cultivated populations of the Chinese medicinal plant Coptis chinensis (Ranunculaceae). Plant Biology. 2008; 10(4):485-491.

52. Yuan QJ, Zhang ZY, Hu J, Guo LP, Shao AJ, Huang LQ. Impacts of recent cultivation on genetic diversity pattern of a medicinal plant, Scutellaria baicalensis (Lamiaceae). BMC Genet. 2010; 11:29.

53. Hu YP, Wang L, Xie XL, Yang J, Li Y, Zhang HG. Genetic diversity of wild populations of Rheum tanguticum endemic to China as revealed by ISSR analysis. Bioch Syst Ecol. 2010; 38:264-274.

54. Wu Y, Xia L, Zhang Q, Yang Q. Habitat fragmentation affects genetic diversity and differentiation of the Yarkand hare. Conserv Genetics. 2010; 11(1):183-194.

\section{How to cite this article:}

Sairkar PK, Chouhan S, Sen A, Sharma R, Singh RK. Genetic drift in six cultivated populations of Terminalia arjuna. J App Biol Biotech. 2017; 5 (04): 048-056. 